\title{
Interaction between cadmium and mercury accumulation by Daphnia magna Straus (Crustacea, Branchiopoda)
}

\author{
Luis OlivaTeles ${ }^{1,2, *}$, Maria F. Alpendurada ${ }^{3}$, Maria N. Vieira ${ }^{1,2}$ \\ ${ }^{1}$ Dept. Zoologia Antropologia, Faculdade de Ciências do Porto, Prç. Gomes Teixeira, 4099002 Porto, \\ Portugal. \\ 2,* Centro Interdisciplinar de Investigação Marinha e Ambiental, Rua dos Bragas 177, 4050-123 Porto, \\ Portugal. \\ ${ }^{3}$ Faculdade de Farmácia do Porto, Rua Aníbal Cunha 164, 4050 Porto, Portugal. \\ * Corresponding author: loteles@fc.up.pt
}

\begin{abstract}
The objective of this study was to evaluate the effects and interactions of various factors on the simultaneous accumulation of cadmium and mercury contaminants. Two chemical forms of mercury $\left(\mathrm{HgCl}_{2}\right.$ and $\left.\mathrm{CH}_{3} \mathrm{HgCl}\right)$ were used in conjunction with inorganic cadmium $\left(\right.$ as $\mathrm{CdCl}_{2}$ ). The effects of direct and trophic modes of accumulation were investigated.

Daphnids (Daphnia magna) were exposed for 5 days to cadmium $\left(\mathrm{CdCl}_{2}\right)$ and mercury $\left(\mathrm{HgCl}_{2}\right.$ or $\left.\mathrm{CH}_{3} \mathrm{HgCl}\right)$ in different combinations and concentrations. Exposure was provided either directly via water, or indirectly by providing contaminated algae (Chlorella vulgaris) as a food source. As it is often the case for aquatic organisms, methylmercury was found to be the form of mercury most efficiently accumulated by $D$. magna. The way of exposure to mercury was also a determinant, with the results depending on the chemical form used. Therefore, even though the preferential way of inorganic mercury accumulation was through the water, the preferential way for D. magna contaminated with methylmercury was through contaminated algae. However, accumulation of Cadmium was not significantly affected by the exposure way. Both cadmium and mercury were able to inhibit each other accumulation. Even though $\mathrm{HgCl}_{2}$ was normally the mercury form that most efficiently inhibited cadmium accumulation, inhibition of $\mathrm{CH}_{3} \mathrm{HgCl}$ was more efficient in the presence of cadmium.
\end{abstract}

Keywords: metal pollution, cadmium, mercury, toxicity, bioaccumulation, Daphnia magna.

\section{RESUMEN}

El objetivo de este estudio fue evaluar los efectos e interacciones de varios factores sobre la acumulación simultánea de cadmio y mercurio. Se utilizaron dos formas químicas de mercurio $\left(\mathrm{HgCl}_{2}\right.$ y $\mathrm{CH}_{3} \mathrm{HgCl}$ ) junto con cadmio inorgánico (como $\mathrm{CdCl}_{2}$ ), y se investigaron los efectos de la vía de contaminación (directa y trófica).

Se expusieron ejemplares de daphnias (Daphnia magna) durante 5 dias a diferentes concentraciones de cadmio $\left(\mathrm{CdCl}_{2}\right)$ y mercurio $\left(\mathrm{HgCl}_{2}\right.$ y $\mathrm{CH}_{3} \mathrm{HgCl}$ ) en varias combinaciones. La contaminación se efectuó directamente a través del agua, o indirectamente a través de algas previamente contaminadas (Chlorella vulgaris). Como suele observarse en organismos acuáticos, el metilmercurio fue la forma de mercurio más eficientemente acumulada por $\mathrm{D}$. magna. La vía de contaminación por mercurio fue también determinante con resultados dependientes de la forma química usada. Por lo tanto, aunque el modo preferente de acumulación de mercurio inorgánico fue a través del agua, en $\mathrm{D}$. magna contaminada con metilmercurio el modo preferente fue a través de algas contaminadas. Sin embargo, la acumulación de cadmio no se vio significativamente afectada por la vía de contaminación. Tanto el cadmio como el mercurio fueron capaces de inhibir el proceso de acumulación del otro metal. Aunque el $\mathrm{HgCl}_{2}$ fue normalmente la forma de mercurio que más eficientemente inhibia la acumulación de cadmio, la inhibición de $\mathrm{CH}_{3} \mathrm{HgCl}$ fue más eficientemente en presencia de cadmio.

Palabras clave: contaminación por metales, cadmio, mercurio, toxicidad, bioacumulación, Daphnia magna. 


\section{INTRODUCTION}

In the experimental model of contamination proposed in this work, Daphnia magna Straus represents a large group of zooplankton present in freshwater. This group, and especially small crustaceans such as D. magna, is of particular interest because it forms the main source of animal protein for carp (Michaels, 1988) - which is the object of study in other projects carried out by our institution.

For ecotoxicologists, daphnids are particularly interesting because they occupy a key position in many freshwater food chains (Hartmann and Kunkel, 1991) and constitute part of the diet of most freshwater fishs (Muus and Dahlstrom, 1968). Most species of freshwater fish consume plankton, obligatorily or facultatively, for at least part of their life cycles (Vasconcelos, 1990). For these reasons daphnids constitute an important way of contamination that should be taken into account, especially when it is considered that they are essentially phytoplanktonophagous and that phytoplankton are noted for their capacity to accumulate certain metallic micro-pollutants (Ting et al., 1989; Ilangovan et al., 1992). Therefore, Daphnids are an essential link in the study of the transfer of heavy metals in an experimental food chain (Vray et al., 1993).

In this test, daphnids were contaminated with cadmium and mercury, combined at different concentrations. The chemicals used were an inorganic compound of cadmium $\left(\mathrm{CdCl}_{2}\right)$ and two compounds of mercury, one inorganic $\left(\mathrm{HgCl}_{2}\right)$, and one organic $\left(\mathrm{CH}_{3} \mathrm{HgCl}\right)$. When dissolved, these compounds give rise to the chemical species of cadmium and mercury which are most common in freshwater: $\mathrm{Cd}^{2+}, \mathrm{HgCl}_{2}, \mathrm{HgOHCl}$, $\mathrm{Hg}(\mathrm{OH})_{2}, \mathrm{CH}_{3} \mathrm{HgOH}$, and $\mathrm{CH}_{3} \mathrm{HgCl}$ (Lum, 1987; Haines et al., 1995; Mason et al., 1995). Contamination of the daphnids was carried out directly, by adding the toxics to the surrounding water, or by feeding the daphnids with previously contaminated algae (Chlorella vulgaris).

The object of this study was to simultaneously evaluate the effects and interactions of various contaminants on the concurrent accumulation of cadmium and mercury, the chemical forms of mercury $\left(\mathrm{HgCl}_{2}\right.$ and $\left.\mathrm{CH}_{3} \mathrm{HgCl}\right)$, and the mode of contamination (direct and trophic). The simultaneous study of all experimental parameters allowed an overall vision of the mechanisms of bioaccumulation of cadmium and mercury in D. magna and resulted in a better approximation of the complex functions of these mechanisms that occur in the natural environment.

\section{MATERIALS AND METHODS}

\section{Material}

All the chemicals used were of analytical quality. The water used in all experiments was double-deionised (resistivity specified as $<2 \mu \mathrm{S}$. $\mathrm{cm}$ ). The daphnids used in this study (D. magna) were obtained by parthenogenetic multiplication of second-generation parents, from a common progenitor. The CBSC strain of the microalgae (unicellular alga) Chlorella vulgaris (Beijerinck) was kindly donated by the Algal Library of the Department of Botany "Dr Júlio Henriques", in the Faculty of Sciences and Technology at the University of Coimbra, Portugal. The synthetic freshwater (ASTM, 1980) used as the experimental medium was prepared aseptically from double deionised water with the addition of $192 \mathrm{mg} \mathrm{L}^{-1} \mathrm{NaHCO}_{3}$, $120 \mathrm{mg} \mathrm{L}^{-1} \mathrm{CaSO}_{4} \cdot 2 \mathrm{H}_{2} \mathrm{O}$ and $8.0 \mathrm{mg} \mathrm{L}^{-1} \mathrm{KCl}$. This medium, according to APHA (1992), has the following physical-chemical characteristics: $\mathrm{pH}$ 7.6-8.0; hardness $160-180 \mathrm{mg} \mathrm{CaCO} \mathrm{L}^{-1}$, and alkalinity $110-120 \mathrm{mg} \mathrm{CaCO}_{3} \mathrm{~L}^{-1}$.

\section{Experimental Design}

The basic Experimental Unit (EU) consisted of 200 daphnids, about 48 hours old, in an Erlenmeyer glass vessel covered with aluminium foil containing 2 litres of synthetic freshwater (ASTM, 1980). The water was renewed each day. The EUs so prepared were placed in a shaded environment, which was maintained at $20 \pm 1{ }^{\circ} \mathrm{C}$. After a 4-day acclimatization period, 
during which the daphnids were fed daily with $7 \times 10^{5}$ cells $\mathrm{mL}^{-1}$ of $C$. vulgaris, the contamination of the EUs with metal pollutants was started as shown in Table 1. The experimental design consisted of four factors (way of exposure, chemical form of mercury, initial cadmium concentration and initial mercury concentration) in a were completely randomised design. Each of the factors consisted of two levels or conditions, giving a total of 16 experiments. In order to maintain the experimental conditions as constant as possible, all experimental media were replaced each day. Thus, the daphnids were exposed daily to different combinations of cadmium and mercury using one compound of cadmium $\left(\mathrm{CdCl}_{2}\right)$ and two compounds of mercury $\left(\mathrm{HgCl}_{2}\right.$ and $\left.\mathrm{CH}_{3} \mathrm{HgCl}\right)$ as contaminants. The type of exposure was either direct (tegumentary) or by algal food (trophic).

For direct contamination, daphnids were transferred each day to new EUs to which two litres of appropriately contaminated ASTM medium had been added. The contamination was performed by a single injection of concentrated $\mathrm{Cd}$ and $\mathrm{Hg}$, to obtain the concentrations shown in Table 1. In order to minimize the amount of contamination of these daphnids by the trophic route, they were starved throughout the test.

For trophic contamination, the daphnids were each transferred to new EUs containing contaminated algal suspensions. These suspensions were prepared the previous day by inoculating glass flasks (one for each contamination condition) containing $6 \mathrm{~L}$ of ASTM medium with $2.5 \mathrm{mg} \mathrm{L}^{-1}$ of algal concentrate. In these culture media, the algae were incubated in a controlled environment, at $20 \pm 1^{\circ} \mathrm{C}$, at a light intensity of about 2000 LUX using two types of fluorescent lamps (Philips TLD 36W and Sylvania GRO-LUX F 36W) and aerated using filtered air bubbled through the cultures. After 2 hours of acclimatization under such conditions, the algal suspensions were contaminated with $\mathrm{Cd}$ and $\mathrm{Hg}$ using the same combination of cadmium and mercury as mentioned above for direct contamination (Table 1). The concentration of algae in the inoculum was cho-

Table 1. Experimental design. Diseño experimental.

\begin{tabular}{|c|c|c|c|c|}
\hline \multirow[b]{2}{*}{ Experiments } & \multirow[b]{2}{*}{$\begin{array}{c}\text { Way of } \\
\text { exposure }\end{array}$} & \multirow[b]{2}{*}{$\begin{array}{l}\text { Chemical form } \\
\text { of mercury }\end{array}$} & \multicolumn{2}{|c|}{ Initial level of contamination } \\
\hline & & & $\underset{\left(\mu \mathrm{g} . \mathrm{L}^{-1}\right)}{\text { Cadmium }}$ & $\begin{array}{c}\text { Mercury } \\
\left(\mu g . L^{-1}\right)\end{array}$ \\
\hline 1 & Trophic & $\mathrm{HgCl}_{2}$ & 0.25 & 0.25 \\
\hline 2 & Trophic & $\mathrm{HgCl}_{2}$ & 0.25 & 1.00 \\
\hline 3 & Trophic & $\mathrm{HgCl}_{2}$ & 1.00 & 0.25 \\
\hline 4 & Trophic & $\mathrm{HgCl}_{2}$ & 1.00 & 1.00 \\
\hline 5 & Trophic & $\mathrm{CH}_{3} \mathrm{HgCl}$ & 0.25 & 0.25 \\
\hline 6 & Trophic & $\mathrm{CH}_{3} \mathrm{HgCl}$ & 0.25 & 1.00 \\
\hline 7 & Trophic & $\mathrm{CH}_{3} \mathrm{HgCl}$ & 1.00 & 0.25 \\
\hline 8 & Trophic & $\mathrm{CH}_{3} \mathrm{HgCl}$ & 1.00 & 1.00 \\
\hline 9 & Direct & $\mathrm{HgCl}_{2}$ & 0.25 & 0.25 \\
\hline 10 & Direct & $\mathrm{HgCl}_{2}$ & 0.25 & 1.00 \\
\hline 11 & Direct & $\mathrm{HgCl}_{2}$ & 1.00 & 0.25 \\
\hline 12 & Direct & $\mathrm{HgCl}_{2}$ & 1.00 & 1.00 \\
\hline 13 & Direct & $\mathrm{CH}_{3} \mathrm{HgCl}$ & 0.25 & 0.25 \\
\hline 14 & Direct & $\mathrm{CH}_{3} \mathrm{HgCl}$ & 0.25 & 1.00 \\
\hline 15 & Direct & $\mathrm{CH}_{3} \mathrm{HgCl}$ & 1.00 & 0.25 \\
\hline 16 & Direct & $\mathrm{CH}_{3} \mathrm{HgCl}$ & 1.00 & 1.00 \\
\hline
\end{tabular}


sen in order to obtain, after 24-h growth, a final concentration of algae close to that considered ideal for the optimum development of daphnids (7x $10^{5}$ cells $\mathrm{mL}^{-1}$, in Lee et. al., 1986).

The algal concentrate used in the experiments was prepared aseptically from an inoculum of $100 \mathrm{~mL}$ of a logarithmic growth phase culture, inglass culture vessels containing $5 \mathrm{~L}$ of culture medium $Z_{8}$ (Kotai, 1972) incubated for 7 days and maintained the same conditions as the contaminated algal suspensions. After this incubation period the cultures were placed in the dark for 3 days at $4^{\circ} \mathrm{C}$ to allow the cultures to settle, the culture medium was then decanted and the cells resuspended in synthetic freshwater (ASTM, 1980).

Taking into consideration the detection limits imposed by the chemical analysis technique used (see below) the levels of metal contamination chosen (Table 1) were as low as possible. For the exposure period used, the concentrations of $\mathrm{Cd}$ and $\mathrm{Hg}$ are considered, separately, to be sub-lethal for D. magna (Delarche and Ribeyre, 1978; Ribeyre et. al., 1981; Kuhn et. al., 1989; Barber et. al., 1994; Gordillo et. al., 1998). Sampling times chosen were 1,3 and 5 days. Two EUs (duplicates) were used for each experimental condition and each sampling time.

To evaluate the background contamination, two additional EUs ("trophic blanks") for each sampling time were prepared in which daphnids were fed with non-contaminated algae. In addition, ten mortality tests were run in which D. magna exposed to the same experimental conditions as the EUs but, lacking direct contamination, were starved in parallel with the test units ("direct blanks").

\section{Analytical methods}

For each sampling time, daphnids from each EU were collected, weighed and stored at $-18 \pm 2{ }^{\circ} \mathrm{C}$ in $3 \mathrm{~mL}$ of $65 \% \mathrm{HNO}_{3}$ (analytical quality). To avoid the loss of mercury by evaporation, the dry weight of daphnids was calculated indirectly using the relationship: "dry weight"/"fresh weight" $=10 \%$, as proposed by Dumont et al., (1975). On the day of analysis of mercury, the acid-stored samples were treated by acid digestion in a $95^{\circ} \mathrm{C}$ oven for three hours and then diluted with $30 \mathrm{~mL}$ of double deionised water. From each diluted sample a $5 \mathrm{~mL}$ aliquot was taken and stored at $0^{\circ} \mathrm{C}$ for subsequent determination of cadmium concentration. The cadmium and mercury concentrations present in the samples were estimated by atomic absorption spectrophotometry (Perkin Elmer 5100 PC). The mercury concentration was assessed, by the method of generation of hydrides, using a commercial FIAS system (Perkin Elmer FIAS 100) under optimized conditions (Oliva Teles et al., 1996), and the cadmium was atomized in a graphite oven (Perkin Elmer HGA 600). Each sample was analysed twice. The concentrations of cadmium and mercury in daphnids are expressed in terms of dry weight.

Quantification of the effects and interactions of the various experimental factors was based on saturated orthogonal multiple linear regression analysis (Box et al., 1978; Tomassone et al., 1983). Mortality was treated statistically through the analysis of variance (ANOVA) and the Newman-Keuls test for homogeneity (Winer et al., 1991). For the multiple regression analysis, a significance level $(\alpha)$ of 0.01 was used. For the ANOVA and Newman-Keuls Test, a significance level of 0.05 was used. All of the statistical analyses were carried out using STATISTICA for Windows Version 4.5 (Statsoft, 1993).

\section{RESULTS}

\section{Mortality Test}

After the five days of the experiment, the mortality rate in the direct "blanks" was rather high (11\% - Table 2). This elevated death rate is probably related to the prolonged fasting to which the daphnia had been subjected and this gravely affected their physiological state. For this reason the test was terminated after 5 days.

All the toxins used in this study $\left(\mathrm{CdCl}_{2}\right.$, $\mathrm{HgCl}_{2}$, and $\mathrm{CH}_{3} \mathrm{HgCl}$ ) were used at concentrations that are individually considered sub-lethal. Despite this, and from the third day of the expe- 
Table 2. Tests of variance of Daphnia magna mortality rate during the 5 days of the experiment, in controls and EUs grouped by way of exposure. Test de la varianza en la tasa de mortalidad de Daphnia magna durante los 5 días del experimento en unidades control y experimentales agrupados por tipos de exposición.

\begin{tabular}{cccccc}
\hline Variance source & Sums of squares & d.f. & Mean squares & F & p-level \\
\hline Between groups & 36991.220 & 14 & 2642.230 & 69.425 & 0.0000 \\
Within groups & 7421.559 & 195 & 38.059 & & \\
\hline
\end{tabular}

Test of homogeinity $(\alpha=0.05)$ - Newman-Keuls test

\begin{tabular}{|c|c|c|c|c|c|}
\hline \multirow[b]{2}{*}{ Groups } & \multirow{2}{*}{$\begin{array}{l}\text { Grouping factors } \\
\text { Way of exposure }\end{array}$} & \multirow[b]{2}{*}{ Day } & \multirow[b]{2}{*}{ Mean mortality } & \multirow[b]{2}{*}{$\mathbf{N}$} & \multirow[b]{2}{*}{ Homogeneous groups } \\
\hline & & & & & \\
\hline 1 & trophic & $1 \mathrm{st}$ & $0.06 \%$ & 16 & $\mathrm{a}$ \\
\hline 2 & direct & $1 \mathrm{st}$ & $1.25 \%$ & 16 & $\mathrm{a}$ \\
\hline 3 & controls (direct blanks) & $1 \mathrm{st}$ & $1.00 \%$ & 10 & $\mathrm{a}$ \\
\hline 4 & trophic & 2nd & $0.22 \%$ & 16 & $\mathrm{a}$ \\
\hline 5 & direct & 2nd & $3.88 \%$ & 16 & $\mathrm{a}$ \\
\hline 6 & controls & 2nd & $1.00 \%$ & 10 & $\mathrm{a}$ \\
\hline 7 & trophic & $3 \mathrm{rd}$ & $0.66 \%$ & 16 & $\mathrm{a}$ \\
\hline 8 & direct & $3 \mathrm{rd}$ & $6.34 \%$ & 16 & $\mathrm{a}$ \\
\hline 9 & controls (direct blanks) & $3 \mathrm{rd}$ & $1.00 \%$ & 10 & $\mathrm{a}$ \\
\hline 10 & trophic & $4 \mathrm{rd}$ & $0.72 \%$ & 16 & $\mathrm{a}$ \\
\hline 11 & direct & $4 \mathrm{rd}$ & $11.72 \%$ & 16 & $\mathrm{~b}$ \\
\hline 12 & controls & $4 \mathrm{rd}$ & $1.67 \%$ & 10 & $\mathrm{a}$ \\
\hline 13 & trophic & $5 \mathrm{rd}$ & $3.22 \%$ & 16 & $\mathrm{a}$ \\
\hline 14 & direct & $5 \mathrm{rd}$ & $51.31 \%$ & 16 & $\mathrm{c}$ \\
\hline 15 & controls (direct blanks) & $5 \mathrm{rd}$ & $11.00 \%$ & 10 & $\mathrm{~b}$ \\
\hline
\end{tabular}

riments, the average rate of mortality in the daphnids contaminated by the direct method was higher than that in the controls (Table 2). This excess in mortality most probably has its origin in the simultaneous exposure to two toxic agents. Some studies on D. magna and other organisms have suggested that some components of a toxic mixture may contribute significantly to the toxicity of the mixture, even though they are below their toxic threshold (Hermens et al., 1985; Biesinger and Christensen, 1972).

\section{Accumulation of metals in D. magna}

During the three sampling times, the concentrations of $\mathrm{Cd}$ and $\mathrm{Hg}$ in the "trophic blanks" (daphnids fed with uncontaminated algae) were not detectable. Therefore, it may be concluded that the contribution to the study metals by components other than the spiked substances is not significant.

\section{Cadmium}

Despite the prolonged exposure time in relation to the short life span of D. magna, the accumulation of cadmium did not reach saturation in any of the tested conditions (Fig. 1).

In a much shorter time ( $40 \mathrm{~h})$, in a study by Penttinen et al., (1995) the accumulation of cadmium by $D$. magna reached saturation although the initial level of contamination was higher $\left(20 \mu \mathrm{g} \mathrm{L}^{-1}\right)$. There may be several reasons for 


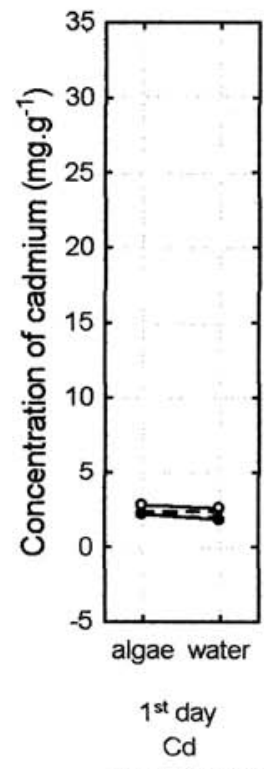

(0.25 ug.L-1)

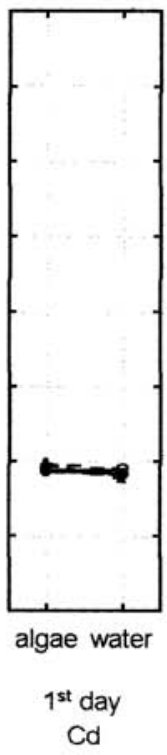

(1 ug.L-1)

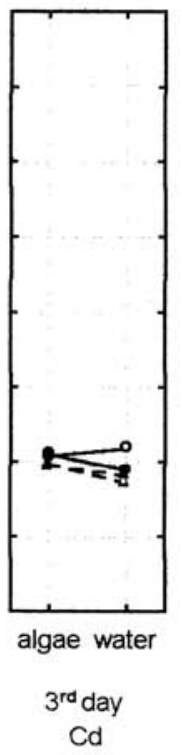

(0.25 ug.L-1)

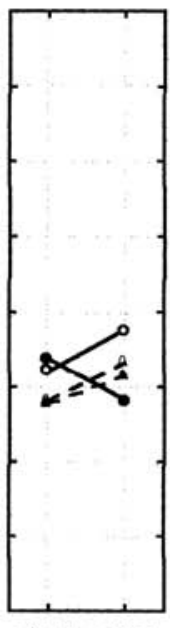

algae water

$$
\begin{gathered}
3^{\text {rd day }} \\
\text { Cd }
\end{gathered}
$$

(1 ug. L-1)

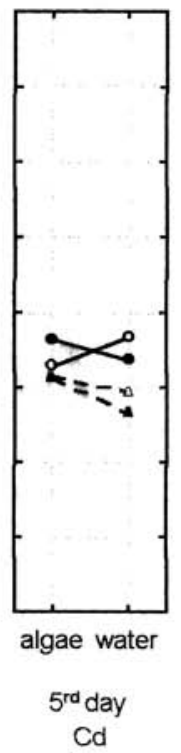

(0.25 ug.L-1)

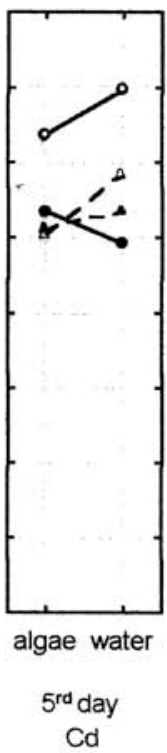

(1 ug.L-1)
$-\triangle-\mathrm{HgCl} 2 \mathrm{x}$

$\mathrm{Hg}(0.25$ ug.L-1)

- - $\mathrm{HgCl} 2 \times \mathrm{Hg}$

$\mathrm{Hg}$ (1 ug.L-1)

- $-\mathrm{CH} 3 \mathrm{HgClx}$

$\mathrm{Hg}(0.25$ ug.L-1)

$\mathrm{CH} 3 \mathrm{HgClx}$

$\mathrm{Hg}$ (1 ug.L-1)

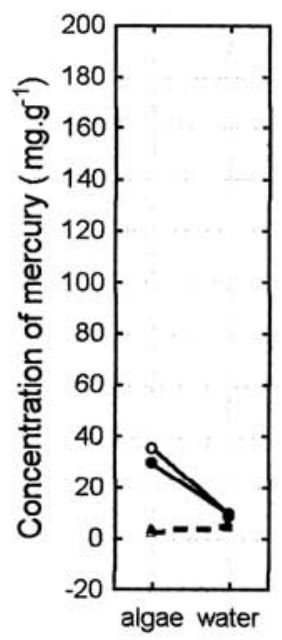

$1^{\text {st }}$ day
$\mathrm{Hg}$
$(0.25$ ug.L- 1$)$
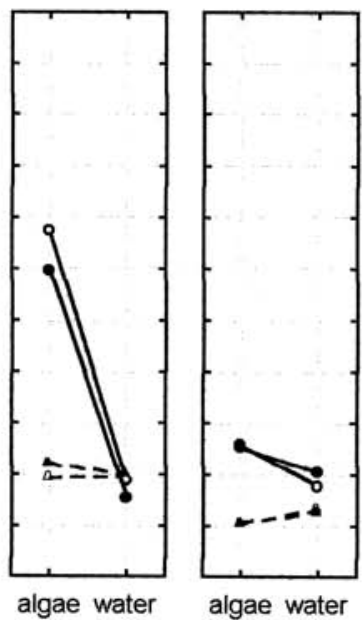

algae water

$$
3^{\text {rd }} \text { day }
$$

$\mathrm{Hg}$

(0.25 ug.L-1)
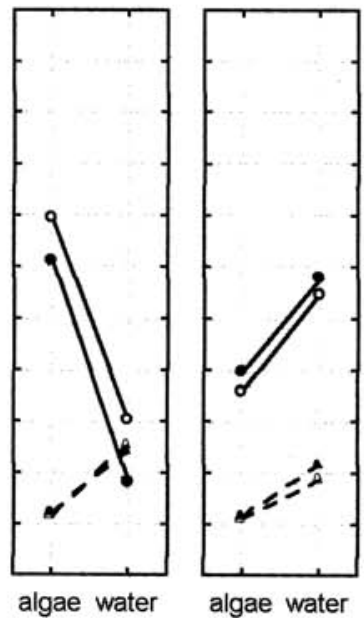

algae water

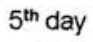

$\mathrm{Hg}$

(0.25 ug.L-1)<smiles>[GeH3]</smiles>

$\mathrm{Hg}$

(1 ug. L-1)

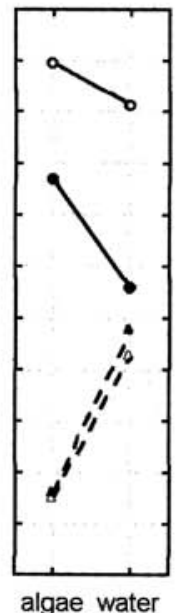

$-\triangle-\mathrm{HgCl} 2 \mathrm{x}$ Cd(0.25 ug.L-1)

- - $\mathrm{HgCl} 2 \times \mathrm{Hg}$ Cd(1 ug.L-1)

- $-\mathrm{CH} 3 \mathrm{HgClx}$ $\mathrm{Cd}(0.25$ ug.L-1)

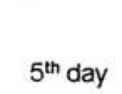

$\mathrm{Hg}$

(1 ug.L-1)
$\mathrm{CH} 3 \mathrm{HgClx}$

$\mathrm{Cd}$ (1 ug.L-1)

Figure 1. Projection of the mean concentration values of cadmium and mercury in Daphnia magna in relation to exposure time and experimental contamination conditions: exposure way (water, algae), chemical form of mercury $\left(\mathrm{HgCl}_{2}, \mathrm{CH}_{3} \mathrm{HgCl}\right), \mathrm{contami}^{-}$ nation level of mercury $[\mathrm{Hg}(0.25 \mu \mathrm{g} \mathrm{L}-1), \mathrm{Hg}(1 \mu \mathrm{g} \mathrm{L}-1)]$ and cadmium contamination level $\left.\left[\mathrm{Cd}\left(0.25 \mu \mathrm{g} \mathrm{L}^{-1}\right), \mathrm{Cd}^{-1} \mu \mathrm{g} \mathrm{L}^{-1}\right)\right]$. Valores medios de la concentración del cadmio y del mercurio en Dapnhia magna de acuerdo con el tiempo de exposición y de las condiciones de contaminación experimental: vía de exposición (vía trófica, vía directa), forma química del mercurio (HgCl, $\left.\mathrm{CH}_{3} \mathrm{HgCl}\right)$, nivel de la contaminación del mercurio $\left[\mathrm{Hg}\left(0.25 \mu \mathrm{g} \mathrm{L}^{-1}\right), \mathrm{Hg}\left(1 \mu \mathrm{g} \mathrm{L}{ }^{-1}\right)\right]$ y nivel de contaminación del cadmio [Cd(0.25 $\left.\left.\mu g L^{-1}\right), C d\left(1 \mu g L^{-1}\right)\right]$. 
this difference, e.g. the physico-chemical characteristics of the water used and, most probably, the simultaneous contamination with mercury, which features in the current work.

A total of $94.94 \%$ of the variation in the concentration of cadmium in daphnids may be explained by the significant variables $(p<0.01)$ in the multiple linear regression analysis (Table $3)$. The greater part of this variation $(92.14 \%)$ may be explained by the variables associated only with the time of exposure (T) and level of contamination of cadmium $(\mathrm{Cd})$ : variables $\mathrm{T}, \mathrm{T}^{2}$, $\mathrm{Cd}$, and Cd.T. As a result of these two factors acting either together or independently, the accumulation of cadmium by daphnids increases with the level of contamination of this metal and with the time of exposure (Fig. 1).

The chemical form of mercury (F), acting either independently or in conjunction with the time of exposure (variables F and F.T), represents $1.43 \%$ of the variation of concentration of cadmium in these daphnids (Table 4). In general, as a result of this action and interaction, daphnids accumulate less cadmium when contaminated with $\mathrm{HgCl}_{2}$ than when contaminated with $\mathrm{CH}_{3} \mathrm{HgCl}$ (Fig. 1).

Table 3. Multiple linear regression analysis of the cadmium concentration in Daphnia magna. Análisis de regresión linear múltiple de la concentración de cadmio en Daphnia magna.

Dependent variable: concentration of $\mathrm{Cd}$ in D. magna ( $\mu \mathrm{g} . \mathrm{g}^{-1}$ dry weight)

\begin{tabular}{|c|c|c|c|c|c|c|c|c|}
\hline \multicolumn{5}{|c|}{ Independent variable } & \multicolumn{4}{|c|}{ Mode } \\
\hline 1 & \multicolumn{2}{|c|}{ Way of exposure } & \multicolumn{2}{|c|}{$(\mathrm{W})$} & & \multicolumn{2}{|c|}{ Trophic and Direct } & \\
\hline 2 & \multicolumn{2}{|c|}{ Chemical form of mercury } & \multicolumn{2}{|c|}{$(\mathrm{F})$} & & \multicolumn{2}{|c|}{$\mathrm{HgCl}_{2}$ and $\mathrm{CH}_{3} \mathrm{HgCl}$} & \\
\hline 3 & \multicolumn{2}{|c|}{ Contamination level of $\mathrm{Cd}$} & \multicolumn{2}{|c|}{ (Cd) } & & \multicolumn{2}{|c|}{$0.25 \mu \mathrm{g} \mathrm{L}^{-1}$ and $1.0 \mu \mathrm{g} \mathrm{L}^{-1}$} & \\
\hline 4 & \multicolumn{2}{|c|}{ Contamination level of $\mathrm{Hg}$} & \multicolumn{2}{|c|}{$(\mathrm{Hg})$} & & \multicolumn{2}{|c|}{$0.25 \mu \mathrm{g} \mathrm{L}^{-1}$ and $1.0 \mu \mathrm{g} \mathrm{L}^{-1}$} & \\
\hline 5 & \multicolumn{2}{|c|}{ Time of exposure } & \multicolumn{2}{|c|}{$(\mathrm{T})$} & & \multicolumn{2}{|c|}{1 day, 3 days and 5 days } & \\
\hline \multirow{2}{*}{\multicolumn{3}{|c|}{$\begin{array}{l}\text { Regression } \\
\text { coefficient (b) }\end{array}$}} & \multirow{2}{*}{\multicolumn{2}{|c|}{ Variable }} & & \multicolumn{2}{|c|}{ Sums of squares } & \multirow[t]{2}{*}{$\mathbf{F}$} \\
\hline & & & & & & values & $\overline{\text { cumulative } \%}$ & \\
\hline \multicolumn{9}{|c|}{$b_{0}=-9.421$} \\
\hline & -6.881 & & \multirow{2}{*}{\multicolumn{2}{|c|}{$\mathrm{Cd}$}} & \multirow[t]{2}{*}{$\mathrm{T}$} & 3030.2 & 60.5 & 1311.1 \\
\hline & -3.331 & & & & & 1065.0 & 81.8 & 460.8 \\
\hline & -2.472 & & \multicolumn{2}{|l|}{$\mathrm{Cd}$} & $\mathrm{T}$ & 391.4 & 89.6 & 169.3 \\
\hline & -0.812 & & & & \multirow[t]{2}{*}{$\mathrm{T}^{2}$} & 126.6 & 92.1 & 54.8 \\
\hline & -0.646 & $\mathrm{~F}$ & & & & 40.0 & 92.9 & 17.3 \\
\hline & -0.703 & $\mathrm{~F}$ & & & \multirow[t]{2}{*}{$\mathrm{T}$} & 31.6 & 93.6 & 13.7 \\
\hline \multicolumn{3}{|c|}{$b_{8}=-0.569$} & \multicolumn{2}{|r|}{$\mathrm{Hg}$} & & 31.1 & 94.2 & 13.5 \\
\hline \multirow{2}{*}{\multicolumn{3}{|c|}{$\begin{array}{l}b_{28}=-0.546 \\
b_{9}=-0.437\end{array}$}} & \multirow[t]{2}{*}{$\mathrm{Cd}$} & $\mathrm{Hg}$ & $\mathrm{T}$ & 19.1 & 94.6 & 8.2 \\
\hline & & W & & $\mathrm{Hg}$ & & 18.3 & 94.9 & 7.9 \\
\hline & -0.499 & & & $\mathrm{Hg}$ & $\mathrm{T}$ & 15.9 & 95.3 & 6.9 \\
\hline & -0.497 & $\mathrm{~F}$ & $\mathrm{Cd}$ & $\mathrm{Hg}$ & $\mathrm{T}$ & 15.8 & 95.6 & 6.8 \\
\hline & -0.396 & & $\mathrm{Cd}$ & $\mathrm{Hg}$ & & 15.0 & 95.9 & 6.5 \\
\hline & -0.350 & $\mathrm{~F}$ & & $\mathrm{Hg}$ & & 11.8 & 96.1 & 5.1 \\
\hline & -0.318 & $\mathrm{~F}$ & $\mathrm{Cd}$ & $\mathrm{Hg}$ & & 9.7 & 96.3 & 4.2 \\
\hline Listed varia & $\mathrm{s}: \mathrm{F}>\mathrm{F}_{0.05}$ & l.f.:1,48) & & & & 4821.4 & 96.3 & \\
\hline Remaining & iables & & & & & 74.3 & 01.5 & \\
\hline Residual & & & & & & 110.9 & 02.2 & \\
\hline Total & & & & & & 5006.6 & 100.0 & \\
\hline
\end{tabular}

(Values in bold type - $\mathrm{F}$ values higher than the critical value for $\left.\alpha=0.01\left(\mathrm{~F}_{0.01}=7.3\right)\right)$ 
Table 4. Multiple linear regression analysis of the concentration of mercury in Daphnia magna. Análisis de regresión linear múltiple de la concentración de mercurio en Daphnia magna.

Dependent variable: concentration of $\mathrm{Cd}$ in $D$. magna $\left(\mu \mathrm{g} \cdot \mathrm{g}^{-1} \mathrm{dry}\right.$ weight)

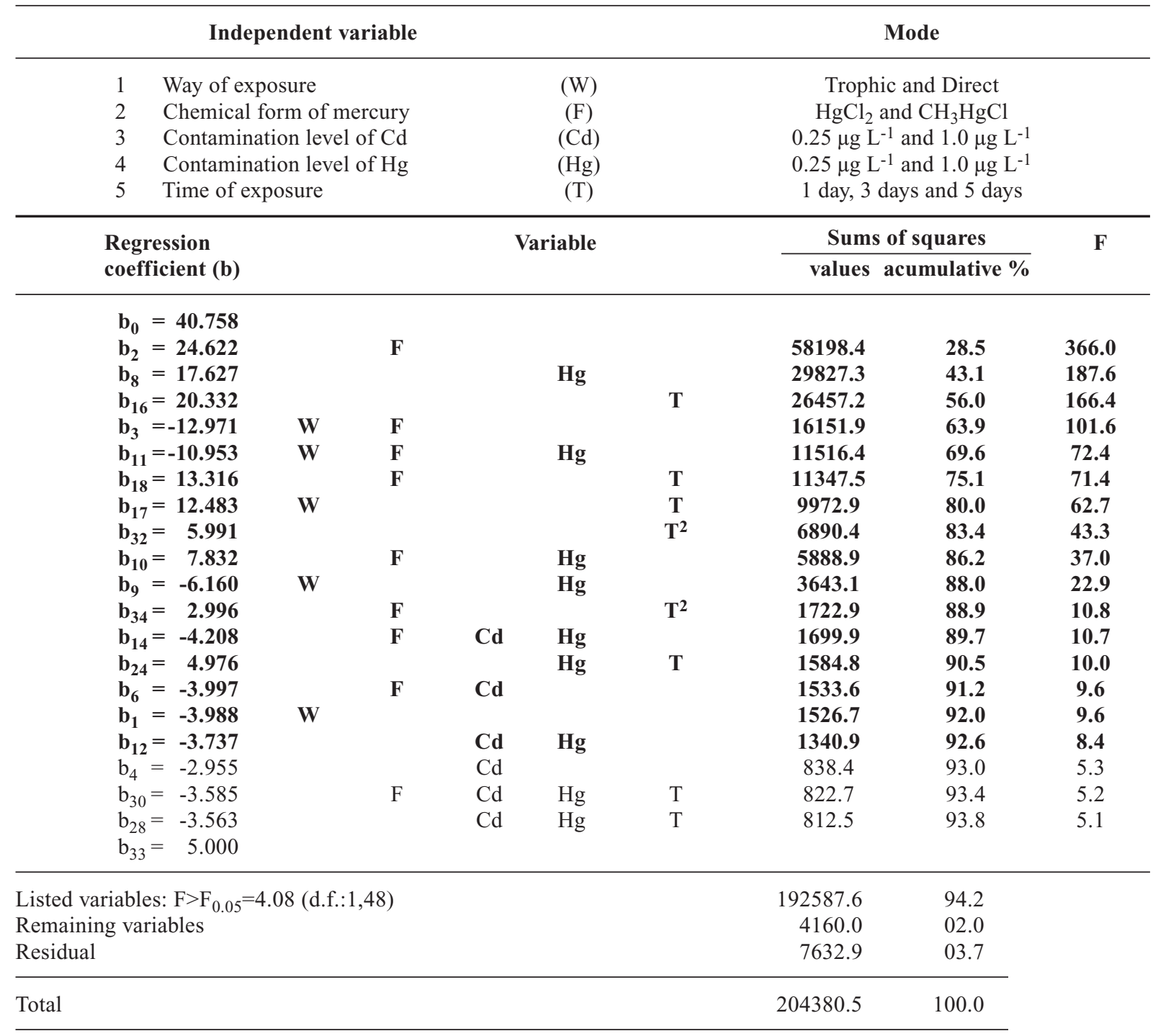

(Values in bold type - $\mathrm{F}$ values higher than the critical value for $\mathrm{a}=0.01\left(\mathrm{~F}_{0.01}=7.3\right)$ )

Acting independently, the level of contamination of mercury (variable $\mathrm{Hg}$ ) generally reduces the concentration of cadmium in D. magna, representing $0.62 \%$ of the variation (Table 4, Fig. 1 ).

Increasing with time, the interaction of cadmium with mercury (variable Cd.Hg.T) also influences, albeit slightly, the accumulation of cadmium by D. magna, representing
$0.38 \%$ of the total variation (Table 4 ). As a consequence of this interaction, the inhibitory effect of mercury on the accumulation of cadmium was most evident at the highest levels of contamination of cadmium and, vice-versa, the effect of the level of contamination of cadmium was most obvious at the lowest level of contamination of mercury (Fig. 1). 
The type of exposure, interacting with the level of mercury contamination (variable W. $\mathrm{Hg}$ ), was the one that least interfered with the variation in the concentration of cadmium in D. magna, representing only $0.37 \%$ of its variation (Table 4). This interaction means that the inhibitory effect of mercury on the accumulation of cadmium was more apparent in the daphnids that were directly contaminated than in those contaminated by algae (Fig. 1).

\section{Mercury}

As was noted for cadmium, the five-day exposure to mercury was not sufficient to allow the accumulation of mercury to reach a saturation point in D. magna contaminated with $\mathrm{CH}_{3} \mathrm{HgCl}$ (Fig. 1). In the daphnids that were contaminated with $\mathrm{HgCl}_{2}$, the five-day period was also insufficient using the direct contamination route. However, it seems that the accumulation of mercury by the trophic method of contamination did reach a limit for both contamination levels after 3 days of exposure (Fig. 1).

Taking into account all the significant variables $(p<0.01)$ of the multiple linear regression analysis shown in Table 4 it is possible to explain $92.62 \%$ of the total variation in the concentration of mercury in D. magna.

Along with the time of exposure, or interacting with it, $90.38 \%$ of the variation mentioned may be explained by the following factors: way of contamination (variable $\mathrm{W}$ ), chemical form of mercury (variable F), level of mercury contamination (variable $\mathrm{Hg}$ ); and all the possible combinations of these three factors. Cadmium alone does not interfere with the accumulation of mercury, although interactions between this factor and others (variables $\mathrm{F}, \mathrm{Hg}$ and $\mathrm{F}$. $\mathrm{Hg}$ ) were significant, contributing with $2.24 \%$ of the total variation.

D. magna contaminated with $\mathrm{CH}_{3} \mathrm{HgCl}$ accumulated more mercury than those contaminated with $\mathrm{HgCl}_{2}$ (Fig. 1). This effect was so important that the chemical form of the contaminant (variable F) was the most significant factor in the accumulation of mercury $(34.87 \%$ of total variation in association with the time factor, Table 4).
When contaminated with the organic form of mercury, daphnids accumulated more metal by the trophic route than by the direct route, but when contaminated with inorganic mercury the opposite effect is noted and the accumulation from water is higher than that from contaminated food (Fig. 1). Thus, there is a strong interaction between the chemical form of mercury and the type of exposure (variable F.W) contributing $7.90 \%$ of total variation (Table 4 ).

The concentration of mercury in these daphnids was also increased by the level of contamination of this metal (variable $\mathrm{Hg}$ ) (Table 4). This factor interacted with the variables $\mathrm{F}, \mathrm{W}$ and F.W so as to increase the effect of these factors at the higher levels of contamination (Fig. 1).

As it has already been noted, the interactions of factor $\mathrm{Cd}$ with factors $\mathrm{F}, \mathrm{Hg}$ and $\mathrm{F}$. $\mathrm{Hg}$ were significant. This suggests that the discussed effects of these factors on the accumulation of mercury generally diminish with the level of contamination of cadmium; and that the inhibitory effects of cadmium on the accumulation of mercury are mostly observed at the higher levels of $\mathrm{CH}_{3} \mathrm{HgCl}$ (Fig. 1).

While discussing the concentration of accumulated mercury in D. magna it should be noted that the organisms contaminated by the direct route were starved during the experiment, while those contaminated by way of normal feeding were not. This produced a considerable distinction between the two groups in that the starved daphnids showed a profound loss of weight over the five-day experiment, which caused an unexpected effect of concentration of mercury. This effect was particularly evident on the fifth day of exposure at the lower level of mercury contamination and it was so important that it was capable of inverting the effect of the route of contamination in the daphnids contaminated with organic mercury $\left(\mathrm{CH}_{3} \mathrm{HgCl}\right)$ (Fig. 1). However, it is not possible to assess the importance of this concentration factor since it was not a part of the experimental design. The accumulation of cadmium by $D$. magna was not apparently affected by the marked loss of weight in the crustacea that were starved (Fig. 1). 


\section{DISCUSSION}

In the present work, the route of contamination interfered little in the accumulation of cadmium in daphnids, i.e., it was not the case of a clear preference for accumulation by the direct route reported in some literature (Cossa and Lassus, 1989). In a study using the freshwater prawn, Procambarus acutus acutus, Giesy et al., (1980) reported that both the food and the surrounding water were important factors in cadmium contamination. However, in other experimental food chains, using chironomid larvae (Chironomus riparius) as prey, and trichopterous (Mystacides spp.) and hydracarinae (Limnesia maculata) as predators, the alimentary route was dominant for cadmium accumulation (Timmermans et al., 1992). Similar results were obtained by Stephenson and Turner (1993), with $53 \%$ of the radioactive cadmium assimilated by Hyalella azteca being incorporated from the food (periphyton). Jennings and Rainbow (1979a, b) also observed that the trophic route was the principal mode of contamination with cadmium in Artemia sp. and Cancer pagurus if the lower trophic levels had the ability to accumulate this metal.

As it has been noted generally for aquatic organisms (Olson et al., 1973; de Freitas et al., 1981; Paulose, 1987; Canli and Furness, 1995), methylmercury was the most efficiently accumulated mercury compound. This characteristic is so important that among all the experimental factors studied the chemical form of mercury was the most important influence on the accumulation of this metal by D. magna.

The contamination route was also significant in the accumulation of mercury by D. magna although the degree of this effect depends on the chemical compound used as the source of contamination. Thus, while the preferred way for the assimilation of $\mathrm{HgCl}_{2}$ was via water, for methylmercury the preferred route was generally via food. Boudou and Ribeyre (1981) obtained similar results in experiments involving contamination of D. magna with the same mercury compounds, but without the addition of cadmium as a co-contaminant.
The distinctly different behaviour of these two forms of mercury may be the reason for the predominance of methylmercury that is normally observed in the tissue of fish at the top of the food chain (Bernhard et al., 1982). Mason et al. (1996) proposed that the incorporation of neutral and lipophylic chloro-complexes, especially $\mathrm{HgCl}_{2}$ and $\mathrm{CH}_{3} \mathrm{HgCl}$, were the principal ways of incorporating mercury in inorganic and organic forms. These authors argued that the different solubilities in lipids did not explain the dominance of methylmercury in fish because the neutral complexes of inorganic mercury are as liposoluble as those of organic mercury. They further suggested that this preponderance of methylmercury in fish was a result of the higher efficiency of methylmercury transfer compared to the inorganic mercury. This phenomenon is confirmed by numerous studies involving a wide variety of aquatic organisms (for example: Boudou and Ribeyre, 1981, 1985; Riisgard and Famme, 1986; Saouter et al., 1989; Riisgard and Hansen, 1990; Watras and Bloom, 1992; Canli and Furness, 1995).

Cadmium and mercury mutually inhibited the accumulation of the other in D. magna but although $\mathrm{HgCl}_{2}$ was the form of mercury that mostly reduced the assimilation of cadmium, it was the assimilation of methylmercury the one most affected by the cadmium. Blazka and Shah (1992) working with Sprague-Dawley rat hepatocytes showed that the accumulation of cadmium by these cells was competitively inhibited by mercury. These authors proposed that the accumulation of cadmium by hepatocytes occurred mainly through the transport processes associated with zinc, copper and iron, involving linkage to -SH groups and that mercury, when linked to these groups, would inhibit the absorption of cadmium. In the same study, and contrary to the findings presented here, the reciprocal finding was not observed. Apart from this study, there appears to be little information in the literature about the interaction between $\mathrm{Cd}$ and $\mathrm{Hg}$ accumulation. Ramamoorthy and Blumhagen observed in 1984 that the rainbow trout (Oncorhyncus mykiss) when subjected to a 
mixture of cadmium, mercury, and zinc absorbed twice as much mercury as they did when exposed only to mercury. This result is in apparent disagreement with the current results in D. magna but the organism used is a very different one and the presence of zinc might have also had a considerable effect.

\section{REFERENCES}

APHA. 1992. Standard Methods for the Examination of water and wastewater, 18 th ed. Washington, DC: American Public Health Association, Inc, $991 \mathrm{pp}$.

ASTM. 1980. Standard practice for conducting acute toxicity testes with fishes, macroinvertebrates and amphibians. Philadelphia: American Society for Testing and Materials, Report E: 729780

BARBER, I., D. J. BAIRD \& P. CALOW. 1994. Effect of cadmium and ration level on oxygen consumption, RNA concentration and RNA-DNA ratio in two clones of Daphnia magna Straus. Aquat. Toxicol., 30: 249-258.

BERNHARD, M., R. BUFFONI \& A. RENZONI. 1982. Mercury in Mediterranean tuna: Why is their level higher than in Atlantic tuna? Thalassia, 18: 2631-243.

BIESINGER, K. E. \& G. M. CHRISTENSEN. 1972. Effects of various metals on survival, growth, reproduction metabolism of Daphnia magna. J. Fish. Res. Bd. Can., 29: 1691-1700.

BLAZKA M. E \& Z. A. SHAIKH. 1992. Cadmium and mercury accumulation in rat hepatocytes: interactions with other metal ions. Toxicology and Applied Pharmacology, 113: 118-125.

BOUDOU, A. et F. RIBEYRE. 1981. Bioaccumulation de deux derives du mercure par un consommateur primaire: Daphnia magna - importances de voies de contamination et du facteur temperature. INSERM, 106: 347-358.

BOUDOU, A. \& F. RIBEYRE. 1985. Experimental study of trophic contamination of Salmo gairdne$r i$ by two mercury compounds $-\mathrm{HgCl}_{2}$ and $\mathrm{CH}_{3} \mathrm{HgCl}$ - analysis at the organism and organ levels. Water Air Soil Pollut., 26: 137-148.

BOX, G. E. P., W. G. HUNTER \& J. S. HUNTER. 1978. Statistics for experimenter. New York: Wiley.
CANLI, M. \& R. W. FURNESS. 1995. Mercury and cadmium uptake from seawater and from food by the Norway lobster Nephrops norvegicus. Environ. Toxicol. Chem., 14: 957-961.

COSSA, D. \& P. LASSUS. 1989. Le cadmium en milieu marin: biogéochimie et ecotoxicologie. Rapports Scientifiques et techniques de l'IFREMER, 16.

de FREITAS, A. S. W., K. M. LLOYD \& S. U. QUADRI. 1981. Mercury bioaccumulation in the detritus-feeding benthic invertebrate, Hyalella azteca (Saussure). Proc. N. S. Inst. Sci., 31: 217 236.

DELARCHE, A. et F. RIBEYRE. 1978. Chaine trophique experimentale en milieu limnique. Thèse de 3ème cycle $\mathrm{n}^{\mathrm{a}} 1436$, Université de Bordeaux I., France. $53 \mathrm{pp}$

DUMONT, H. J., I. DE VELDE \& S. DUMONT. 1975. The dry weight estimate of biomass in a selection of Cladocera, Copepoda and Rotifera from the plankton, periphyton and benthos of continental waters. Oecologia, 19: 75-97.

GIESY, J. P., J. W. BOWLING \& H. J. KANIA 1980. Cadmium and zinc accumulation and elimination by freshwater crayfish. Arch. Environ. Contam. Toxicol., 9: 683-697.

GORDILLO, S., F. PEREIRA y J. F. VALE PARAPAR. 1998. Evaluación de la ecotoxicidad aguda de metales pesados con Daphnia magna Straus. Ecotoxicology and Environmental Restoration, 1: 3-12.

HAINES, T. A., V. T. KOMOV, V. E. MATEY \& C. H. JAGOE. 1995. Perch mercury content is related to acidity and color of 26 Russian lakes. Water Air Soil Pollut. 85: 823-828.

HARTMANN, H. J. \& D. KUNKEL. 1991. Mechanisms of food selection in daphnids. Hydrobiologia, 225: 129-154.

HERMENS, J., E. BROEKHUYZEN \& R. WEGMAN. 1985. Quantitative strcture-activity relationships and mixture toxicity studies of alcohols and chlorohydrocarbons: effects on growth of Daphnia magna. Aquatic Toxicol., 6: 209-217.

ILANGOVAN, K., M. SALAZAR, D. SUDHAKAR, O. H. MONROY \& C. A. RAMOS. 1992. Interaction of cadmium, copper and zinc in Chlorella pyrenoidosa Chick. Environ. Technol., 13: 195-199.

JENNINGS, J. R. \& P. S. RAINBOW. 1979a. Studies on the uptake of cadmium by the crab Carcinus maenas in the laboratory: I. 
Accumulation from seawater and food source. Mar. Biol., 50: 131-139.

JENNINGS, J. R. \& P. S. RAINBOW. $1979 \mathrm{~b}$. Accumulation of cadmium by Artemia salina. Mar. Biol., 51: 47-53.

KOTAI, J. 1972. Instrution for preparation of modified nutrient solution Z8 for algae. Norwegian Institute for Water Research. Oslo. $5 \mathrm{pp}$.

KUHN, R. M. PATTARD, K. D. PERNAK \& A. WINTER. 1989. Results of the harmful effects of water pollutants to Daphnia magna in the 21 day reproduction test. Water Res., 23: 501-510.

LEE, C. M., C. A. TURNER \& E. HUNTINGTON. 1986. Factors affecting the culture of Daphnia magna. In: Aquatic toxicology and environmental fate. Poston, T.M., Purdy, R. (eds.). 19 ASTM STP 291: 357-368. American Society for Testing and Materials, Philadelphia, USA.

LUM, K. R. 1987. Cadmium in fresh waters: the Great Lakes and St. Lawrence River. In: Cadmium in the aquatic environment. Nriagu, J. O., Sprague, J.B. (Eds.): 35-50. John Wiley \& Sons, New York.

MASON, R. P., J. R. REINFELDER. \& F. M. MOREL. 1995. Bioaccumulation of mercury and methylmercury. Water Air Soil Pollut., 80: 915921.

MASON, R. P., J. R. REINFELDER \& F. M. M. MORE. 1996. Uptake, toxicology, and trophic transfer of mercury in a coastal diatom. Environ. Sci. Technol., 30: 1835-1845.

MICHAELS, V. K. 1988. Carp Farming. Fishing News Books Ltd., Farnham. 208 pp.

MUUS, B. J. et P. DAHLSTROM. 1968. Guide des poissons d'eau douce et pêche. Delachaux et Niestlé SA ed., Neufchâtel, Suisse. 228 pp.

OLIVA TELES, L., M. R. SILVA e M. F. ALPENDURADA. 1996. Optimização de um método de doseamento do mercúrio total em amostras biológicas. Revista Portuguesa de Farmácia, 47: 145148.

OLSON, K. R., H. L. BERGMAN \& P. O. FROMM. 1973. Uptake of methylmercury chloride and mercuric chlorid by trout: a study of uptake pathways into the whole animal and by erythrocytes in vitro. J. Fish. Res. Board. Can., 30: 1293-1299.

PAULOSE, P. V, 1987. Bioaccumulation of inorganic and organic mercury in a freshwater mollusc, Lymnaea acuminata. J. Environ. Biol., 8: 185189.

PENTTINEN, S., J. KUKKONEN \& A. OIKARI.
1995. The kinetics of cadmium in Daphnia magna as affected by humic substances and water hardness. Ecotoxicol. Environ. Saf., 30: 72-76.

RAMAMOORTHY, S. \& K. BLUMHAGEN. 1984. Uptake of $\mathrm{Zn}, \mathrm{Cd}$, and $\mathrm{Hg}$ by fish in the presence of competing compartments. Can. J. Fish. Aquat. Sci., 41: 750-756.

RIBEYRE, F., A. BOUDOU et A. DELARCHE. 1981. Contamination d'une chaine trophique experimentale par le methylmercure: Importance du systeme "producteur - consommateur primaire". Environ. Pollut. Ser. A 24 : 193-206.

RIISGARD, H. U. \& P. FAMME. 1986. Accumulation of inorganic and organic mercury in shrimp, Crangon cangron. Mar. Pollut. Bull., 17: 255-257.

RIISGARD, H. U. \& S. HANSEN. 1990. Biomagnification of mercury in a marine grazing food chain: algal cells Phaeodactylum tricornatum, mussels Mytilus edulis and flounders, Platichthys flesus studied by means of a stepwise-reductionCVAA method. Mar. Ecol. Prog. Ser., 62: 259270.

SAOUTER, E., F. RIBEYRE \& A. BOUDOU. 1989. Bioaccumulation of mercury compounds $\left(\mathrm{HgCl}_{2}\right.$ and $\mathrm{CH}_{3} \mathrm{HgCl}$ ) by Hexagenia rigida (Ephemeroptera). In: Heavy metals in the environment (VII), Vol. 1. Vernet (ed.): 378-381. CEP Consultants, Edinburgh.

STATSOFT. 1993. Statistica (Version 4.5) Tulsa, OK. USA.

STEPHENSON, M. \& M. TURNER. 1993. A field study of cadmium dynamics in periphyton and in Hyalella azteca (Crustacea: Amphipoda). Water Air Soil Pollut., 68: 341-361.

TIMMERMANS, K. R., E. SPIJKERMAN \& M. TONKES. 1992. Cadmium and zinc uptakes by two species of aquatic invertebrate predators from dietary and aqueous sources. Can. J. Aquat. Sci., 49: 655-662.

TING, Y. P., F. LAWSON \& I. G. PRINCE. 1989. Uptake of cadmium and zinc by the alga Chlorella vulgaris. I. Individual ions species. Biothechnol. Bioeng., 34: 990-999.

TOMASSONE, R., E. LESQUOY et C. MILLIER. 1983. La régression-nouveaux regards sur une ancienne méthode statistique. Masson. Paris. 180 pp.

VASCONCELOS, V. M. 1990. Impacte de estirpes tóxicas e não tóxicas de Microcystis aeruginosa em Daphnia longispina. Relatório para uma aula prática, apresentado para efeito do disposto no 
número 1 do Art. 58 Decreto-lei 448/79 de 13 de Novembro, Faculdade de Ciências, Universidade do Porto. 35 pp.

VRAY, F., M. SVADLENKOVA et J. P. BAUDIN. 1993. Accumulation et élimination du ${ }^{106} \mathrm{Ru}$ par Daphnia magna Straus. Etud des vois directe et trophique. Annls. Limnol., 29: 281-293.
WATRAS, C. J. \& N. S. BLOOM. 1992. Mercury and methylmercury in individual zooplankton: implications for bioaccumulation. Limnol. Oceanogr., 37: 1313-1318.

WINER, B. J., D. R. BROWN \& K. M. MICHELS. 1991. Statistical principals in experimental design. (3rd ed.). New York: McGraw-Hill. 
